\title{
Cięcie (epistemologiczne)
}

ERWERSYJNY PRZEWODNIK PO IDEOLOGIACH SLAVOJ ŽŽ̌EK OTwIERA odwoła-
niem do filmu Oni żyją. Obraz Johna Carpentera z 1988 r. opowiada o bezdomnym mężczyźnie, przypadkowo odnajdującym okulary, dzięki którym dostrzec można przekaz ideologiczny, ukryty pod kolorowymi reklamami, krzykliwymi nagłówkami gazet i nobliwymi portretami martwych prezydentów, umieszczonymi na banknotach. I tak spoza reklamy koncernu informatycznego wyziera nagle wezwanie „Bądź posłuszny”, spod bilbordu zachęcającego do wypoczynku w tropikach - hasło „Pobierajcie się i rozmnażajcie”, zaś na banknotach dolarowych widnieje w istocie dosadna deklaracja wiary: „Oto twój bóg”. Nie posiadające magicznych okularów krytyki ideologii, nieświadome masy społeczne nie są w stanie rozpoznać manipulacji, której ulegają.

Słoweńskiemu filozofowi medium filmowe służy za przedmiot analizy, a zarazem środek, za pomocą którego ukazuje działanie stosowanych przez siebie narzędzi krytycznych. W jego przypadku jest to Lacanowska psychoanaliza, lecz z równym powodzeniem, odwołując się do wybranych dzieł filmowych, objaśniać można istotę takich podejść jak krytyka postkolonialna, krytyka genderowa bądź dekonstrukcja. Wszystkie one są specyficznym sposobem lektury, usiłującym ukazać odmienne interpretacje, alternatywne wobec odbioru bezrefleksyjnego - a więc właśnie ideologicznego. Według S. Žižka ideologią zarażamy się bowiem mimochodem, czy może raczej ideologia jest właśnie tym, co przyjmujemy bez zastanowienia, uznając za normalne.

Sednem krytyki ideologii wydaje się być $\mathrm{w}$ związku z tym nieustanne kwestionowanie przekonania, iż to, co zwykłe (gdyż codziennie doświadczane) jest jednocześnie neutralne. Ideologia nie musi docierać do nas przecież w formie nachalnej propagandy. Najczęściej, zwłaszcza w państwach demokratycznych, programowanie myślenia obywateli dokonuje się w sposób trudniejszy do zidentyfikowania. W tym programowaniu tkwi zresztą największe niebezpieczeństwo ideologii: od jej treści bądź formy niepomiernie groźniejsze jest wykształcanie przez nią automatyzmu myślenia. $\mathrm{W}$ efekcie nasze mniemania o świe- 
cie stają się schematyczne, czego my jednak - jeśli nie wyposażymy się w odpowiednie narzędzia krytyczne - nie potrafimy dostrzec.

Dlatego też S. Žižek namawia nas, byśmy ideologię próbowali rozpoznać nie w tym, co jawne, lecz w tym, co ukryte. Jest to zgodne z przenikającym całą myśl postmodernistyczną, a sięgającym przynajmniej ontologii Martina Heideggera, myśleniem przez pryzmat negatywności. Podobnie przecież Michel Foucault rozumiał dyskurs, kategorię, którą zastąpić można w niektórych przypadkach pojęcie ideologii. Według M. Foucualta przedmiotem naszego zainteresowania powinny być mechanizmy kontrolowania procesu wytwarzania dyskursu, przede wszystkim procedury wykluczenia. Mechanizmy te funkcjonują jak nożyce, wycinające z kadru wszelkie elementy, które psują pożądaną kompozycję obrazu. Dlatego zamiast skupiać się na tym, co dostrzegalne, pytać należy o to, czego nie widać.

Pamiętać zarazem należy, iż nie istnieje perspektywa poznawcza pozbawiona mechanizmów kontroli dyskursu. Nawet te podejścia, które przedstawiają się jako najbardziej otwarte, pozostają ślepe na pewne aspekty rzeczywistości i nietolerancyjne wobec innych dyskursów, próbujących podejścia te zakwestionować. Ci, którzy dziś protestują przeciw dominującemu dyskursowi, po przejęciu władzy sami zaczną stosować wykluczenie. Znaczy to zatem tyle, że żadna perspektywa nie może sobie rościć prawa do bycia finalną, nawet jeśli - posługując się językiem postmarksistowskim - zdobędzie chwilową hegemonię. Za przejściowym tryumfem tej czy innej wizji zwykle nie stoi bowiem dająca się obiektywnie zmierzyć przewaga epistemologiczna. Przynajmniej od czasu publikacji prac Thomasa Kuhna wiemy przecież, że poszczególne wizje świata pozostają względem siebie niewspółmierne - niemożliwe jest stwierdzenie, która z nich lepiej opisuje i wyjaśnia rzeczywistość. Dlatego coraz częściej ocena roszczeń perspektyw poznawczych dokonuje się w rejestrze aksjologicznym. To sprzyjanie - lub nie - danego podejścia określonym wartościom etycznym wydaje się być dla wielu decydującym (a niekiedy pierwotnym i nieuświadomionym) kryterium wyboru tej bądź innej metody interpretacji rzeczywistości. Najgorzej, gdy przyjęcie lub odrzucenie danej perspektywy związane jest z panującą modą bądź klimatem intelektualnym i politycznym. Ulegając presji środowiskowej, chcąc wpisać się w chwilowe trendy, badaczki i badacze mogą utożsamiać się z pewnymi podejściami w sposób płytki i pozbawiony zrozumienia lub stosować je jako manifestację własnych przekonań politycznych. Także w ten sposób ideologia przenikać może do nauki. 
Czy opisane wyżej problemy skłaniać nas zatem powinny do porzucenia wszelkich nadziei na uzyskanie wiedzy niezideologizowanej? A może, jeśli chcemy pozostać krytyczni wobec ideologizacji naszego postrzegania świata, zaakceptować musimy poznawczy relatywizm i indyferencję? Gdyby tak było, jedyną stabilną postawą byłby pogardliwy, sarkastyczny sceptycyzm. Lecz nie o to w nauce chodzi. Postawa krytyczna nie oznacza krytykanctwa, charakterystycznego dla okresu intelektualnej adolescencji. Immanuel Kant wskazuje, iż w procesie rozwoju rozumu ta młodzieńcza faza sceptycyzmu jest wprawdzie postępem wobec niemowlęcego dogmatyzmu, jednak dojrzałość daje dopiero ugruntowany krytycyzm. „Sceptycyzm”, czytamy w najważniejszym dziele filozofa z Królewca, ,jest dla ludzkiego rozumu miejscem wypoczynku, gdzie może on się zastanowić nad swą dogmatyczną wędrówką i naszkicować plan okolicy, w której się znajduje, by móc w przyszłości obrać z większą pewnością swą drogę. Nie jest jednak miejscem zamieszkania na stałe, to bowiem da się znaleźć jedynie w zupełnej pewności poznania czy to samych przedmiotów, czy też granic, w których obrębie jest zamknięte wszelkie nasze poznanie przedmiotów”. Inaczej jeszcze rzecz ujmując: dla niespokojnego, krytycznego rozumu, cel jest mniej istotny niż ruch.

W tym kontekście krytyka ideologii realizuje cele tożsame z filozofią - jest próbą wyćwiczenia w sobie cnoty ustawicznego zdziwienia rzeczywistością. Jednak nie dla wszystkich taki trwały stan niepokoju, stan permanentnego dysonansu poznawczego, będzie znośny. Niektórym łatwiej jest uzbroić się w lańcuchy tautologii, przyswoić parę pojęć jak cepy, i z wyższości własnego dogmatu sądzić żywych i umarłych. Niestety, i tego nie brakuje w pejzażu intelektualnym i ideowym współczesnej Akademii. Dlatego ciągle tak ważne jest budzenie ludzkich rozumów, a przez to zapobieganie pojawieniu się (anty)intelektualnych demonów.

Z tym większą satysfakcją oddajemy do rąk Czytelniczek i Czytelników dziesiąty już numer „Refleksji” - pisma, którego celem od samego początku było rozbudzanie zdziwienia światem, prezentowanie różnych obszarów badawczych i perspektyw poznawczych, a przez to - usiłowanie uniknięcia dogmatyzmu i ideologiczności. „Refleksje” pozostają przede wszystkim miejscem naukowego debiutu i doskonalenia warsztatu badawczego studentów i doktorantów. Jest to rola niezwykle odpowiedzialna, albowiem bardzo ważne jest, by przyszli badacze od samego początku swojej drogi naukowej kształcili w sobie krytycyzm, rzetelność i uczciwość - cnoty nie tylko przecież naukowe. 
Mamy nadzieję, że nasze pismo w tym procesie służy i wciąż służyć będzie pomocą wszystkim tym, których trawi nieuleczalny niepokój poznawczy.

Filip Biaty

Redaktor naczelny 